\title{
CDK6 Gene Amplification
}

National Cancer Institute

\section{Source}

National Cancer Institute. CDK6 Gene Amplification. NCI Thesaurus. Code C132897.

A molecular genetic abnormality indicating the presence of multiple copies of the CDK6 gene. 